\title{
Introduction
}

Margaret Foster, Leslie Kurke, and Naomi Weiss

Our music in those days was divided according to its own forms and postures. There was a form of song comprising prayers sung to the gods, called "hymns"; opposite to this was another form of song which someone might well call "dirges." "Paeans" were another. Then there was yet another called the "dithyramb," which was about the birth of Dionysus, I believe. They gave the name "laws" [nomoi] to another form of song-this sort was for the kithara, they used also to say. Once these, and certain others, had been arranged, it was not allowed to misuse one form of song for another .... But later, with the passage of time, the poets became rulers and held sway over unmusical lawlessness. Although by nature poetic, the poets were ignorant about what is just and lawful for the Muse. In a sort of Bacchic frenzy, more overwhelmed by pleasure than they should have been, they jumbled together dirges with hymns and paeans with dithyrambs; they used kithara sounds to imitate the sounds of the aulos - they confounded everything.

PLATO, Laws 7ooa9-e1, tr. PANGLE

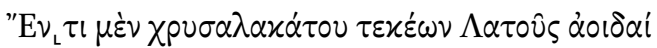

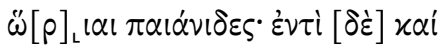

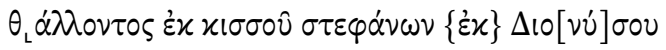

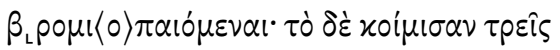

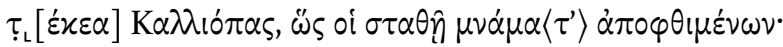

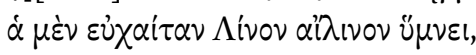

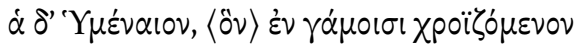

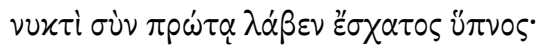

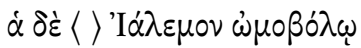

10

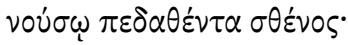

viòv Oiárpou $\langle\delta \dot{\varepsilon}\rangle$

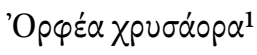

1 The text of this fragment is quoted in the scholia to Eur. Rhes. 895, preserved in only one thirteenth-century ms which seems to have been copied from an already damaged or corrupted text, so the text of the fragment is very troubled. We mainly follow the texts of Maehler 2001 and Race 1997, which are very similar (Race simply includes a few more supplements in 
There are songs for the children of gold-spindled Leto, paean [songs] in due season, and there are also [songs] for Dionysus' crowns of flourishing ivy, [songs] smitten with wine/drunkeness. But, [in contrast to those], [other songs] put to sleep three sons of Calliope, in order that memorials of the dead be set up for her: one [song] sang ailinon for Linus with beautiful hair; another [sang] of Hymenaeus, whom the last sleep took when his skin was touched in marriage together with the first night. And another sang Ialemus, shackled in strength by flesh-rending disease. But the son of Oeagrus, Orpheus with his golden lyre ...

PINDAR, fr. 128c SM

The conference on which this volume was based was organized originally to revisit and interrogate the question of genre, what it means, and how to think about it for archaic and classical Greek poetry. Coming together almost fifty years after the performance model of lyric genre first developed, our speakers were encouraged to engage with a wide array of scholarship, theory, and comparative material in the hope that a more holistic understanding of the concept and its relevance to the study of ancient texts might emerge. ${ }^{2}$ In this same spirit we do not begin this introduction to the volume with one particular definition of genre, since we want to foreground and allow for the different approaches of our contributors, which together push beyond current dominant trends within the field.

We begin instead with a famous passage of Plato's Laws, juxtaposed to a much less familiar fragment of Pindar, because both seem to offer us tantalizing views of an illud tempus of perfect, pure emic genre. These texts seem to speak of a world of clear, recognizable, and distinct generic forms based on addressee or figure celebrated/commemorated; context or occasion of performance; and singers and audience. ${ }^{3}$ The two together point to a system of specific song types in which the umbrella term "lyric" (including poetry composed in melic, iambic, and elegiac meters) is too broad to be meaningful, while

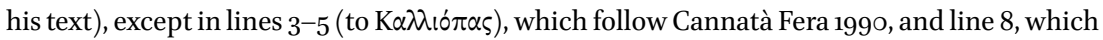
includes in the text the suggested emendations of Henry 1999. Thanks to Donald Mastronarde for sharing with us his new transcription of the scholion and Pindar fragment, examined under UV light, and for extensive discussion of the textual difficulties and merits of different proposed emendations.

2 On literary genre in general: Dubrow 1982; Fowler 1982; Frow 2015. On genre in anthropology/ sociolinguistics: Briggs and Bauman 1992; Bauman 200o. On genre within Classics: Conte 1994; Depew and Obbink 20ooa; Barchiesi 20o1; Bakola, Prauscello, and Telò 2013; Maslov 2015: 40-97, 246-317.

3 Calame 1974 also juxtaposes these two texts, in the service of a somewhat different argument. 
Plato here in the Laws and Pindar also limn a generic system that precedes and seems to operate at a skew line to the much later tripartite division of epic, drama, and lyric as the three "natural kinds" of mimetic poetry. ${ }^{4}$ The latter system itself ultimately depends on and goes back to models developed by Plato in the Republic and Aristotle in the Poetics, which make mimesis- "imitation" or "representation" - the defining feature of verbal art. ${ }^{5}$ Thus our two quoted passages suggest a rift or gap between an emic poetic genre system and the theories of poetry later developed within the culture ${ }^{6}$ while they also seem to open up a window onto a precious archaic system of song in performance that preceded and was innocent of the Classicizing systems and definitions ("the three natural kinds") later imposed upon it.

And yet, slight discrepancies between these two texts already suggest cracks in the surface of our pure genre world, or perhaps better-multiple sedimented layers within a centuries-long stratigraphy of genre. ${ }^{7}$ Thus the Laws passage uses the Greek term humnos narrowly as a technical term for a song comprising prayer to a god (akin to our "hymn"), while the same term functions as a much more general term for choral song in Pindar and throughout archaic Greek poetry. ${ }^{8}$ A.E. Harvey, in a foundational article in 1955 , "The Classification of Greek Lyric Poetry," called attention to the fact that all that we have of archaic and classical Greek lyric poetry comes to us mediated through the editorial work of Hellenistic Greek scholars, who of necessity had to sort and classify a great mass of heterogeneous material into books (papyrus rolls of 1,00o-2,ooo lines) organized by kind. Where we can discern the terms of that classification system best (in the cases of Pindar and Bacchylides), it is clear that there is some divergence or misfit between the original performance occasions of many of these preserved texts and the broader generic labels that the Hellenistic scholars developed to organize them into books (e.g., "epinician" was not a functional category in the archaic and classical period; Pindar himself desig-

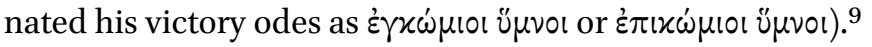

4 For these three as the "natural kinds," see Genette 1992.

5 Although, as Genette 1992 notes, Plato and Aristotle themselves do not develop the threefold model of "natural kinds," since they basically omit lyric from their systems as not obviously mimetic in the way that epic and drama are.

6 Cf. Ford 2002, Farrell 2003.

7 For the terms "sedimentation" and "stratigraphy," cf. Maslov 2015: 22-33, following Veselovsky and Jameson 1981.

8 On this discrepancy, cf. Harvey 1955: 165-168. Calame 1974: 119-12o helpfully reframes this as an issue of signifier vs. signified - the signifier humnos (or paean, or dithyramb) endures, but what it signifies shifts over time. For the meaning of humnos in early Greek poetry, see also Maslov 2015: 294-307.

9 Harvey 1955: 158-164; cf. Agócs 2012: 194-197, Maslov 2015: 279-28o. 
Harvey therefore advocated cautious skepticism about the generic labels we have inherited for various earlier Greek poetic texts: is a "paean" always a "paean"? Does it have to have a refrain? Is a dithyramb always a dithyramb? Can we accept one Hellenistic definition that a dithyramb is always a narrative poem? Harvey himself did not advocate the complete rejection of the generic terms that have come down to us, citing this very passage of Plato's Laws to stabilize the system and argue that many of its terms preexisted the work of the Hellenistic scholars (mainly in the domain of choral lyric). ${ }^{10}$

All of this means that in the domain of early Greek poetic forms, we inherit phenomena of kaleidoscopic complexity: an abundance of material (most of it preserved in fragmentary form) in different meters (iambic, elegiac, and melic), much of it quoted and embedded in other Greek texts which frame, contextualize, and sometimes label these poetic scraps by genre (possibly anachronistically). Given the wild heterogeneity and fragmentation of what has come down to us and the uneven stratigraphy of generic labels, how do we make sense of all this material?

Harvey himself pointed one way forward, by contrasting Hellenistic taxonomies with the original purpose and occasion of a given ancient song. ${ }^{11}$ Such an approach to genre in archaic and classical Greek poetry was given additional impetus and support by the development of models for the oral composition of Homeric poetry - the argument that the highly formulaic nature of Homeric epic gave evidence that this poetry was orally composed in performance by skilled bards in a centuries-long tradition. Oral formulaic theory, developed in relation to Homer by Milman Parry and Albert Lord, prompted much more expansive interest in orality within Greek studies, as constituting forms of culture, poetic composition, and performance radically different from those of the modern literate world. The extension of the model of orality beyond Homer to all of archaic and classical Greek poetry down to the end of the fifth century в Се had a profound impact on the modeling of poetic performance and poetic kinds for this period. ${ }^{12}$ Bruno Gentili, inspired by the work of Parry, Lord, and especially Eric Havelock, insisted on the sheer difference or strangeness of Greek poetic production compared to modern poetry. For Gentili, Greek poetry

10 Harvey 1955: 164-174. Although Harvey does not note the connection with choral lyric, because he does not accept choral vs. monody as a real distinction (159 n. 3), and because he wants to argue for the connection of threnos with elegy, Calame 1974 notes the predominance of choral lyric forms here.

11 Harvey 1955: 159-16o.

12 See Lord 1960 [2000]; Parry 1971. The oral model was significantly extended beyond Homer by Havelock 1963, 1982 . 
was "an essentially practical art," "closely linked to the realities of social and political life," always composed for performance before a specific audience and on a specific occasion..$^{13}$ Performance, audience, memory, and practical function became the key terms, and Gentili drew on comparative oral theory and anthropology to help him imagine how archaic and classical Greek poems functioned within their original contexts of performance.

Within this turn to orality and performance, Claude Calame and Gregory Nagy developed innovative models of genre, and these models still represent an influential paradigm within the field. ${ }^{14}$ Claude Calame, a student of Gentili, in 1974 offered "Réflexions sur les genres littéraires en Grèce archaïque." Here he identified genre not just with a set of immanent formal features to be discerned through structuralist/semiotic analysis of the poetic system, but also with occasion and the "horizons of expectation" of audiences à la H.R. Jauss. ${ }^{15}$ Gregory Nagy, a student of Albert Lord, extended Calame's analysis in the mid-199os with an important article entitled "Genre and Occasion" (on which he elaborates with reference to Sappho in this volume).${ }^{16}$ Here Nagy simultaneously correlated genre with occasion and performance with the Austinian "performative," allowing him to define (Greek) genre as "the set of rules that produce a speech act." ${ }^{17}$ Nagy, however, dissociated the "speech act" from Austin's philosophical context of individual agency and judgment, identifying it instead as "myth" (a narrative significant for a community) performed as "ritual." Within these terms, "the occasion is the genre," but Nagy also added that "if the occasion is destabilized or even lost, the genre can compensate for it, even re-create it."18

Nagy combined the latter idea (genre as a compensation for or recreation of occasion) with a bold and thoroughgoing reconceptualization of mimesis in early Greek poetry. For Nagy, the primary meaning of mimesis in the early

13 Quotations from Gentili 1988: 3; see also A.T. Cole's Translator's Introduction to that volume.

14 We will not attempt to summarize here all the relevant work of Calame and Nagy, since both are incredibly prolific scholars who have over decades (and hundreds of publications) developed, elaborated, and nuanced their thinking on genre. We will instead focus on a couple of their earliest and most influential articles on the topic. For a fuller bibliography of Nagy's work, see his Keynote in this volume; for a representative selection of Calame's work, see the volume bibliography.

15 Calame 1974.

16 Nagy 1994-1995. This article represents a concise summary of the much more expansive presentation of these arguments in Nagy 1990 and Nagy 1996.

17 Nagy 1994-1995:13. Nagy draws the term "speech act" from Austin 1975; in thinking of genre in terms of the principles producing a speech act, he draws on Todorov 1990.

18 Nagy 1994-1995:13 (emphasis in original). 
Greek context was "ritual reenactment," whereby the choral performers of a song for the duration of the performance actually became and embodied the mythical figures whose stories they sang. This model of mimesis endured into Attic tragedy, but when the myth-ritual-performance system came to be destabilized or eroded, the primary meaning of mimesis was lost and a secondary meaning, "imitation," came to the fore. ${ }^{19}$ Hence, Plato's critique of poetry in the Republic as "mere" mimesis ("imitation") is simply a misunderstanding of the older system. By this reorientation, Nagy reconciled the older Greek system of genre based on occasion and performance with the Platonic/Aristotelian model of verbal art defined as mimesis - two systems that otherwise seem to operate at skew lines to each other.

The revolutionary oralist/performance/occasion paradigm of Gentili, Calame, and Nagy can be seen, in turn, as a reaction to older approaches to Greek poetry. It was first a rejection of an idealist Hegelian, teleological reading of the slow unfolding or "discovery" of the Greek Geist through the progressive stages of epic, lyric, and tragedy. This approach, mainly associated with Bruno Snell and Hermann Fränkel, celebrated Greek lyric as the earliest revelation of the subjective "I" in moments of high emotional intensity, in contrast to the serene third-person narration and objective distance of epic. ${ }^{20}$ At the same time, the emphasis on song in performance also represented a rejection of New Criticism and other kinds of formalism, with their turn away from history and context. New Criticism, a powerful movement outside of Classics in the 195os, remained the dominant paradigm for the close reading of poetry within Classics even into the 196os and 7os, while the work of Elroy Bundy in the early 196os, pursuing rigorous rhetorical, topological analysis of Pindaric epinician, spawned another strain of formalism native to the field of Greek poetry. ${ }^{21}$ Although Bundy insisted that everything in epinician served the purpose of praising the victor, both "victor" and "praise" became completely bland generic categories, and Bundy and his followers ranged freely over all of Greek literature and across all its genres to find comparanda for different motifs and motif sequences in the odes. $^{22}$

In response to all this, the approaches of Gentili, Calame, and Nagy represented a return to a different kind of history and context, combined (especially

19 Nagy 1994-1995; cf. Nagy 1996 chs. 1-4. For similar arguments, see Jones 1962 on tragedy as masked drama, and Vernant 1991 chs. 9-10 on the image in Greek culture ("from the presentification of the invisible to the imitation of appearance").

$20 \quad$ See (e.g.) Snell 1946; Fränkel 1975.

21 Bundy 1986 [1962].

22 For this characterization of Bundyist formalism, cf. Cole 1988: xvi. 
in the case of Calame and Nagy) with structuralist/semiotic methodologies. Their ideas of history — all different from the older Hegelian, teleological model of Snell and Fränkel - were also different from each other. And along with different versions of history, we find different models of the lyric "I." For Gentili, the historical context for melic, iambic, and elegiac poems is local and specific, their speakers engaged in quotidian political and social struggles that their verses perform before different interested audiences. ${ }^{23}$ Calame draws more heavily on the history of religion, invoking anthropological models of initiation and rites of passage to situate and make sense of the poetic remains of Alcman and Sappho. In this anthropological modeling, the focus shifts from the historical and biographical ego to the essential communal functions of poetry in performance, with the ego filling the social/structural role of chorus leader or chorodidaskalos. ${ }^{24}$ For Nagy, the influence of oral formulaic theory, the study of Homer, and structuralist and Indo-European linguistics are paramount, so that history is itself embedded in the language and meters of Greek poetry and its traditional formulae. Thus Nagy effectively mines the deep history in texts, reconstructing elements and motifs all the way back to Indo-European, through the reading of all of Greek poetry together as one continuous "macrotext" or signifying system..$^{25}$ Consonant with these reading strategies, the "I" for Nagy becomes a "generic I," a traditional speaking position thrown up or generated by each separate genre over hundreds of years of performance. We should therefore think of "Homer" as the arch-poet of heroic epic; "Hesiod" as the equivalent for theogonic poetry; "Theognis" as the alibi or placeholder for disaffected aristocrats in sympotic elegy throughout the Greek world; and "Sappho" as the lyric "sister" speaking for a long traditon of women's song on archaic Lesbos. ${ }^{26}$

The oralist/performance/occasion paradigm has been an exceptionally productive model within Greek literary studies, stimulating a wide array of significant scholarship over the last forty-five years or more. As we have noted, it remains an influential paradigm in approaches to genre for archaic and classical Greek poetry, especially in north American and continental scholarship. The conference upon which this volume is based opened with this paradigm, with a Keynote Address by Gregory Nagy, and several of the papers here take their cue from the fundamental work of Nagy and Calame.

23 Gentili 1988; for a similar modeling of the "historical I," cf. Rösler 1980, 1985.

24 See esp. Calame 1977, 1983, 1997a.

25 See esp. Nagy 1974, 1979/1999.

26 For the "generic I," see Nagy 1994-1995: 20; for Homer and Hesiod, see Nagy 1982; for Theognis, Nagy 1985; for Sappho, Nagy 2016 and in this volume. 
And yet, like any paradigm, it has its limits-inevitably, in complementary distribution to the things the model fits better are the things it occludes or ignores. ${ }^{27}$ Thus one might say that this paradigm represents an overweighting of the anthropological, the ritual, and the communal over against the literary, the fictional or fictive, and the tussle or dialectic of individual instantiation and tradition. This overweighting inevitably produces two different effects or tendencies - occlusions or blindspots on different scales - both of which have unnecessarily isolated the study of archaic and classical Greek poetry from important trends in the literary humanities. First of all (as Andrew Ford notes in his contribution to the volume), the structuralist method of Calame and Nagy does not deal well with the individual poem - with the texture of the literary in all its specificity and complexity. ${ }^{28}$ This isolates us from a broader movement within the humanities, where there has been a significant return to formalism and theoretically-informed formalist analysis. ${ }^{29}$ At the same time, the insistence of this anthropological/performance paradigm that archaic and classical Greek poetry is radically strange and different from all that came after it has succeeded only too well. For it has cut us off from significant conversations about the longue durée of literary history current throughout the broader humanities. Here one might think of the heated debates around the transhistorical existence of "the lyric" and lyric history represented by Jonathan Culler's 2015 Theory of the Lyric and the New Lyric Studies advocated by Virginia Jackson and Yopie Prins. ${ }^{30}$

Indeed, a similar discontent with the influential anthropological occasion/ performance model animates another recent volume (also based on a conference in 2015), Textual Events: Performance and the Lyric in Early Greece, edited by Felix Budelmann and Tom Phillips. ${ }^{31}$ The editors and contributors to this volume push back against the sociopolitical or ideological reading of archaic Greek lyric, aiming instead to recuperate all the formal, sensuous, and imaginative powers and effects of these texts that they contend such readings elide. Instead, they offer the concepts of archaic Greek poetry read as "literature" and as "textual events," where by "event" they mean the power of highly-wrought

27 See de Man 1983 on the necessary inter-implication of "blindness" and "insight" in any theoretical approach.

28 Cf. Culler 1975: vii-viii, 113-130, 258-259, explicitly acknowledging that his "structuralist poetics" has no interest in offering new readings of individual poems.

29 See, e.g., Best and Marcus 20o9; Felski 2015; Levine 2015.

$30 \quad$ For the debate, see Jackson 2005; Yaeger 2008; Jackson and Prins 2014; Culler 2015. Another relevant trend is the Russian-influenced "Historical Poetics" of Boris Maslov and Ilya Krieger; see Maslov 2015; Krieger and Maslov 2016.

Budelmann and Phillips 2018, based on an Oxford conference in March 2015. 
literary texts to conjure other worlds and new possibilities of feeling, perception, and thought. ${ }^{32}$ We are very much in sympathy with the "New Formalist" turn that the Textual Events volume offers. At the same time, our volume can be read as complementary to that of Budelmann and Phillips, zeroing in on related issues that they do not tackle explicitly, through engagement with a wider range of texts and theoretical approaches. Thus, for example, as Budelmann and Phillips note in their introduction, they do not "attempt to address ... head-on" "the challenges posed by genre in Greek lyric and by Greek lyric as a genre," even while "genre is a thread that runs through" the essays in the volume. ${ }^{33}$

In contrast, the purpose of this volume is explicitly to revisit the concept of genre in archaic and classical Greek poetry nearly fifty years after the significant interventions of Gentili and Calame, and nearly thirty years after Nagy's influential work of the 1990s. The essays in the volume illustrate the different ways in which we can expand upon the advances we have made within this paradigm, while also moving beyond the anthropological occasion/performance model. In many cases, the essays build on theories, models, and lines of argument already current in the field-some of which have themselves developed out of the older paradigm; others derive from the interaction or creative borrowing of Greek studies from other disciplines (including Latin literary studies, art history, dance theory, and affect theory, among others).

We begin with the Keynote Address of Gregory Nagy. ${ }^{34}$ In a return to his study on genre and occasion, Nagy refines his formulation of the paradigmatic term "occasion" by identifying it as an instance of mimesis in the sense of "ritual reenactment." Turning to Sappho, Nagy understands the experiences and emotions that constitute Sappho's songs as belonging above all to the personae who inhabit her song world. An event expressed by a given song, such as a familial crisis or a bout of unrequited love, does not itself prompt the occasion of its own choral performance. Rather, for Nagy, it is the mimesis of such events, performed by a singing and dancing chorus, that comprises the occasion.

32 See Budelmann and Phillips 2018a: for "literature" or the "literary," see pp. 9-15; for "textual events," see pp. 6-10, 23-26. For this concept of "event," they follow the philosopher Alain Badiou; see Badiou 2013 and Payne 2018.

33 Budelmann and Phillips 2018a: 19-22; all quotations from p. 19. Likewise, they note that they will not explicitly tackle the "much discussed issue of lyric mimesis" (p. 9, n. 12), which this introduction and many of our contributors consider from different angles.

34 Appropriately enough, given his focus on oral performance and occasion, Nagy has opted to preserve the oral, lecture quality of his talk at the original conference. We have therefore labeled Nagy's contribution as a "Keynote," and tried, as much as possible, to preserve its performative qualities in the text. 
Nagy's Keynote is followed by three contributions that engage with and/or critique the anthropological/performance paradigm from different perspectives. Andrew Ford challenges an illud tempus or "pre-lapsarian" model of a perfect fit between text and performance occasion in archaic Greece. He argues that we need to move beyond both the idea of poetry as mimesis and that of lyric mimesis as ritual reenactment, proposing instead that we think of genre in terms of "generification"- the ongoing process of its production. Timothy Power rethinks the "choral hypothesis" for Sappho's lyrics, which has long been a crucial component of the anthropological/performance paradigm of Calame and Nagy, arguing instead for a model of "parachorality" that would allow for a more substantial fictive component in the setting of Sapphic song. Finally, Francesca Schironi's paper reconsiders the centrality of performance by turning to an entirely different body of material — the scholia, especially those on Pindar-and investigating how the issue of mimesis (or "speaking personae") was conceptualized in Alexandrian scholarship. As Schironi discovers, references to performance (in our sense) are largely absent from the scholia; they view the chorus instead simply as one more speaking persona. Thus for these ancient readers at least, all early Greek poetry (including Homer) is read mimetically as if it were drama.

We then proceed to two clusters of papers whose approaches in many cases develop out of the anthropological paradigm, but also offer ways beyond it, in dialogue with a variety of other disciplines, theories, and methods. The papers in the first cluster-those of Steiner, Weiss, and Foster-all complicate the notion of "pure" genre from different perspectives. The remaining papers of Griffith, Telò, Estrin, and Olsen all engage with ideas of affect, materiality, and embodied experience to reconsider in different ways current approaches to genre in the study of Greek poetry.

Rather than summarize each essay here, we will lay out programmatically three themes or methodological trends that figure prominently in the rest of the volume. These three themes are not mutually exclusive; often individual essays instantiate two or even three of them at once, and in doing so together herald a new, integrated approach to genre in archaic and classical Greek poetry.

\section{Genre Mixing}

As far back as we can go, there is no "before" of pure or pristine genre that we can locate in our texts. Traditionally, scholars have recognized that, in the Hellenistic and Roman periods, there was constant complex genre mixing, 
generic self-consciousness, and dynamic play with genre within texts, but the current oralist/performance model has tended to exempt archaic Greece as an illud tempus of pure genre in performance. ${ }^{35}$ And yet, Homer and tragedy have always presented significant exceptions to this model. Thus, as Richard Martin has argued, Homeric epic is better defined as a "super-genre" that subsumes within it a multiplicity of "genres of discourse," emic speech genres like flyting, advising, remembering, and mourning as well as lyric forms more narrowly defined, like paean, threnos, and Linus song. ${ }^{36}$ In her essay in this volume, Naomi Weiss proposes that we extend the term "super-genre" to Attic tragedy as well, since (as has become more and more apparent in recent years) tragedy is the ultimate appropriative cultural system, folding into itself all the multifarious resources of the Greek "song culture" for its complex multimedia art. ${ }^{37}$

But genre mixing, complexity, and dynamic play are also evident in our preserved examples of archaic elegiac, iambic, and melic poetry (even if not, in most cases, on the same scale as in Homer and tragedy). Nor can all of these effects be put down to the fragmentary state of our remains, or to the underspecification or "indeterminacy" of genre. ${ }^{38}$ This is patently true for the epinicia of Pindar and Bacchylides, as well as their other choral songs. ${ }^{39}$ So, for example, scholars still debate whether Bacchylides 17 is a paean or a dithyramb, or an amalgam of both, while Margaret Foster explores the complex, "polyphonic" genre mixing of Bacchylides $16 .{ }^{40}$ But for a much earlier example, we might consider the Cologne Epode of Archilochus. In the influential reading of Gregory Nagy, the Cologne Epode is blame poetry_but blame poetry mas-

35 Examples of the earlier consensus: Kroll 1924; Rossi 1971; Zetzel 1983; Barchiesi 2000; Farrell 2003; etc. This is also the framework of Nagy 1994-1995, who quotes Williams 1968 for this point.

$36 \quad$ Martin 1989, 2005.

37 On the incorporation of different genres within tragedy, see esp. Herington 1985, from whom we draw the phrase "song culture" (although Herington focuses mainly on epic in tragedy); Nagy 199o: 382-413; Rutherford 1994-1995; Swift 2010; Kurke 2013b; Weiss 2018. For a more political approach to the appropriative nature of Attic tragedy, see Kowalzig 2006, 2007a; Foster 2017.

38 For "generic indeterminacy," see Carey 1995: 97 and n. 21; Rutherford 2001: 3-10, 90-91; Currie 2005: 21-24; Lowe 2007.

39 For genre mixing in different Pindaric epinicia, see Kurke 1988, 199o, 2013b; Carey 1995; Maslov 2015; for genre mixture in Bacchylides, Fearn 2007: 87-16o. See also Barchiesi 2001: 153 on the prevalence of genre mixture or "transgeneric texts" in the fifth and fourth centuries BCE, as well as Phillips 2018 and Thomas 2018, considering genre mixture within Pindar's ninth paean and the Homeric Hymn to Hermes, respectively.

40 On the genre(s) of Bacchylides 17, see Schmidt 1990; Zimmermann 1992: 91-93; Van Oeveren 1999; Kowalzig 2007b: 88-94; Calame 2009; Tsagalis 20o9; D’Alessio 2013. 
querading as erotic idyll. This tale of man and maid dallying in a meadow works all the more effectively as blame because of its seductive narrative surface; in the course of the poem, the speaking ego manages to destroy the reputations of both the older sister, Neoboule (by what he says about her) and the unnamed younger sister (by what he does to her in the course of the poem). ${ }^{41}$

We see such generic play in this poetry because, as Boris Maslov has convincingly argued, by the time we encounter the whole Greek system, it is already a literary system, subject to the mediation of multiple levels of dynamic genre production and proliferation. ${ }^{42}$ Another way of formulating this might be to say, in Bakhtin's terms, that the texts as we encounter them are always already participants in "secondary genres," literary forms that have absorbed "primary genres" of spontaneous verbal interaction like greeting, prayer, victory announcement, or the "Ie Paian" cry. ${ }^{43}$ Such a model of primary and secondary genres can help elucidate Nagy's double definition of genre as both occasion and compensation for a lost occasion. ${ }^{44}$ In Bakhtin's terms, Nagy's first definition applies to primary speech genres, the second to secondary or derived speech genres once they have developed into literary forms. In these terms, the illud tempus of pure, unmediated genre as performance and occasion is not directly available to us; it can only be a scholarly mirage.

Importantly, as Maslov also notes, there need be no necessary or strict correlation between the crystallization of a complex second-order literary system and a broader cultural shift from orality to literacy. ${ }^{45}$ The too-rigid dichotomy between these two terms (orality and literacy) dominated past scholarship, and with it an unexamined equation of "oral" (oral composition, oral performance, oral transmission) with the immediacy of pure, performative emic genres of song. And yet, there has been a seismic shift in thinking about orality and literacy beyond Classics and within it from the days of Eric Havelock

\footnotetext{
$41 \quad$ Nagy 1976.

42 Maslov 2015: 9-22, 36-116. For the idea that literary discourse is more highly "genred," Maslov follows Silverstein 1993.

43 On "primary" and "secondary genres," see Bakhtin 1986, esp. 6o-67 and the lucid summary of Maslov 2015: 42-47. This distinction is already acknowledged in Harvey 1955: 172-174, who notes the difference between the spontaneous, ritual paean — which may be simply the "Ie Paian" refrain—and the "literary" paeans of Pindar and Simonides.

44 Nagy 1994-1995: 13, discussed above, p. 5.

45 Bakhtin, in his general formulation of the categories "primary" and "secondary genre," had mainly aligned secondary genres with the written (vs. the oral), but, as Maslov 2015: 43 notes, secondary genres like epic or aetiological myth may develop independently of writing.
} 
and Walter J. Ong. ${ }^{46}$ There is now a recognition that the two forms interact unevenly, coexisting and cooperating for long periods of time, and that there are significant continuities as well as differences between oral and literate cultures. ${ }^{47}$ But this broader shift in the cultural and sociological modeling of the orality-literacy interface has rarely penetrated the discourse on the genres of archaic Greek poetry. Indeed, even within a pure oralist model, the extraordinary generic mixture and generic self-consciousness of Homeric epic should itself call into question the alignment of orality with pure performance genre.

So, for example, Andrew Ford's essay in this volume argues that, as far back as we can go, we find our poets always already engaged in self-conscious play with genre. Ford suggests that the poets are themselves "ethnographers of genre," citing Pindar fr. $128 \mathrm{c}$ SM (to which we will return) and Homer's elaborate, punning allusion to two different accounts of the generic origins of Linus song embedded in Iliad 18. Ford is thus extending backward in time the model of generic play and generic complexity much more commonly associated by scholars with Hellenistic and Roman poetry. ${ }^{48}$ Ford usefully introduces the term "generification" to suggest that, from the point of view of production, genre is a dynamic process, always in flux, which is only crystallized retrospectively through reception. ${ }^{49}$

We might combine Ford's concept of dynamic, ongoing "generification" with two important points made by Joseph Farrell in his article "Classical Genre in Theory and Practice."50 First, Farrell notes a significant gap between ancient literary theory and ancient poetic practice when it comes to genre. The ancient theory of genre was essentializing and moralizing, assuming unproblematic, clear boundaries between genres and a hierarchy of genres or literary kinds neatly correlated with the social status and moral character of the poets who worked within them. In contrast, ancient poetic practice was consistently more sophisticated and more complex than ancient theory—and even the explicit statements of ancient poets-allowed..$^{51}$ Second, as one element of such com-

46 For the traditional model of orality vs. literacy, see Havelock 1963, 1982; Ong 1982; cf. Goody and Watt 1968; Miller 1994.

$47 \quad$ Harris 1989; Thomas 1989, 1992; Kirk forthcoming.

48 See esp. the discussions of Barchiesi 2000, 2001 and Farrell 2003; both Barchiesi and Farrell acknowledge that the same kind of generic play and generic complexity can be found in archaic and classical Greek poetry, although both focus more on Roman material.

49 Cf. Todorov 1990: 13-21; this is, in a sense, already the point of Harvey 1955.

5 Farrell 2003.

51 Farrell 2003: 386-396; note esp. Farrell's discussion of the weird misfit between Horace's 
plex generic play or self-consciousness within poetic texts, Farrell notes that genre is often articulated within a dyadic structure of contrast or difference. Thus, for example, in Pindar's second Pythian ode, the speaking "I" elaborately contrasts himself with the noxious Archilochus, "fattening himself on heavyworded hatreds" (Pyth. 2.55-56). The name "Archilochus" here stands for blame poetry, which Pindar, the consummate praise poet, eschews or disavows. ${ }^{52}$ In one sense, Farrell's point is a structuralist one: we might say that genre is a system of differences with no positive terms. ${ }^{53}$ That is to say, genres can only be defined and articulated in a contrastive system with other adjacent or opposed genre categories. And yet, in deconstructive terms, as Farrell points out, each genre then seems inevitably to subsume or include its "other," in a necessary inter-implication of discourses. ${ }^{54}$

With the conceptual apparatus provided by Maslov, Ford, and Farrell, we might return to the passages from Plato's Laws and Pindar quoted at the start. These passages have generally been read, together or separately, to stabilize and substantiate the existence of an unproblematic system of pure, unmixed emic genres. ${ }^{55}$ But we should perhaps pry these two passages apart and recognize how profoundly different they are in their goals and models of genre. To consider the passage from Plato's Laws first: given the misfit convincingly demonstrated by Farrell between ancient theory and ancient practice, why should we believe Plato at all? Why accept that there was ever a time of pure, unmixed or "uncontaminated" genres? ${ }^{56}$ Plato's goal here is obviously political,

explicit injunctions against genre-mixing and his own (deeply mixed and hybridized) form in the Ars Poetica (pp. 393-395).

52 Farrell 2003: 387-388, following Nagy 1979: 222-228. Cf. Barchiesi 2001: 156 on how Roman poets "tend to stage programmatic respect to a traditional genre, precisely to be able to dramatize their work as deviation or genre-bending; the whole process is part of the semiotics of poetry, not a disinterested confession or the disclosure of a true laboratory. To this end, they need genres to be perceived as strong, pure, and sufficiently unmixed; they practice a reconstructive approach to genre, not a capricious reshuffling."

53 This is famously Saussure's definition of language as a structuralist system (Saussure 1972 [1916]).

54 Farrell 2003: 387-389: "Our Pindaric illustration indicates a persistent tendency on the part of Greek and Roman poets to declare their generic allegiances (or to comment on the generic constraints that they faced) in dyadic terms. Such declarations frequently take the form, 'I am doing X, which is to say, the opposite of Y.' This habit discloses a keen awareness on the poets' part that the different genres in question are more than casually linked. Indeed, each necessarily includes the other within its conceptual framework, as an opposite to be sure, but one that is very like a twin." (quote from pp. $388-389$ ). For a broader deconstruction of genre along similar lines, see Derrida 1980.

55 So, e.g., Harvey 1955; Calame 1974; Rutherford 1994-1995.

$5^{6}$ Cf. Barchiesi 2001: 153: "Are we encouraged to construct an age of generic purity as a foil 
as he extends the essentializing modeling of genre from poets to audiences, and from moral/ethical capacities to political forms and their degeneration. ${ }^{57}$ The period of distinct musical genres is presented as emblematic of a reverence for "ancient laws" more broadly, which the Athenian Stranger aims to replicate in the new colony of Magnesia; the dissolution of such laws marks the beginning of "excessive freedom" in the wake of the Persian Wars. Despite the loose historical framing, this is a nostalgic myth about the Athenian past rather than an historical (let alone Panhellenic) reality. Plato here adopts the sort of dyadic approach to genre discussed by Farrell, constructing a Golden Age of pristine genres in order to stage its subsequent breakdown.

Pindar's threnos fragment is up to something else entirely. First, against the taxonomic, genre-stabilizing reading of this fragment, we should note that our text is not a treatise offering objective evidence for the ancient Greek genre system, but a poem-in fact, a threnos or mourning song composed on commission for the family of a deceased individual. ${ }^{58}$ Papyrus fragments of Pindar's threnoi confirm that this is the beginning of the poem, which offers an elaborate priamel of different occasions/genres of song: paeans for Apollo and Artemis, dithyrambs for Dionysus, then three different mourning songs named for and originally sung over three mortal sons of Calliope who died prematurelyLinus, Hymenaeus, and Ialemus. Finally, the poet mentions Orpheus as "son of Oeagrus," just at the point where our fragment breaks off.

This moment is, as Ford notes in his essay in the volume, an instance of Pindar's own poetic anthropology or meta-narrative about the aetiology of genre in particular occasions. ${ }^{59}$ But what has not been emphasized enough is how extraordinary it is for Pindar to construct a priamel from different kinds or genres of lyric song. There are several parallels in Pindar for an opening priamel that serves to focus in on the poet's theme or topic, but what is unique here is the use of different occasions/genres of song for that opening focus-

precisely because we work too hard on the Kreuzung model in Alexandrian literature? Is respect for genre always a 'good old days' feature, as Plato wants us to believe when his agenda is indicting generic anarchy in the Laws?"

57 For a strong political reading of this passage of Plato, see Rancière 2004, with discussion and explication by Hallward 2006, Halpern 2011. See also Folch 2015: 121: "[this] eclectic generic history ... is not about genres per se, but a theory of moral and political psychology worked out in generic terms."

58 That it is a threnos is confirmed by POxy 2447 , fr. $4 \mathrm{~b}$, which preserves the first few letters of the first lines of fr. 128c SM in what is clearly a book of threnoi. See Cannatà Fera 199o: 137 .

Cf. Ford 2002: 15-16. 
ing device. ${ }^{60}$ As such, the priamel bespeaks a remarkable level of poetic selfconsciousness, and offers an excellent example of Farrell's point that ancient poets often articulate genre through explicit contrast and differentiation from neighboring or opposed genres. Here, however, it is not a simple "dyadic structure," but something much more complicated, as we shall see in a moment. In addition, since the terms of the priamel are also the very medium of song and we have no explicit introductory statement like, "What kind of song should I sing?" ${ }^{61}$ we might read the opening lines as a deliberate misdirection that is potentially also transgressive. For when the song begins, we may think we are hearing a paean. If so, this would seem to be a violation of a religious taboo, not to invoke Apollo or sing his characteristic song-type in the context of death and mourning. ${ }^{62}$ On this reading, Pindar is not simply cataloguing, but also promiscuously mixing "hymns with dirges, paeans with dithyrambs" - precisely the decadent miscegenation of genres the Athenian Stranger of Plato's Laws so deplores. The opening is thus, at the very least, unsettling - a weird and intense generic mise-en-abîme.

But, given what we know of Pindar's practice in priamels elsewhere, this may be an even more complicated example of genre mixture or genre hybridization. As Maria Cannatà Fera notes in discussing this fragment and its priamel opening, Pindar's priamels tend to pivot or shift topic or domain on their third term. ${ }^{63}$ As she analyzes this priamel, the structure is (A) songs to gods (subtypes paean and dithyramb); (B) mourning songs for mortal men (subtypes Linus song, Hymenaeus, Ialemus song); and (C) Orpheus. Although we have lost the context, this progression makes it very likely that the mention of Orpheus here has some other function; he is not simply an example of yet another dead mortal for whom songs mourn. ${ }^{64}$

6o Contrast the parallel opening priamels cited by Cannatà Fera 1990: 138: Ol.11.1-4, Ol.1.1-4; the former specifies different times when rain and winds are useful, the latter names and contrasts water, gold, and the sun.

61 For parallels for this kind of set-up, see Pind. Ol.13.11-23, Nem.10.1-18, Isthm.7.1-15. For a similar conceit, cf. Homeric Hymn to Apollo (III), lines 19-50, 207-216.

62 For the taboo on mixing Apollo/paean with death and mourning, see Aesch. Ag. 10721079, fr. 161 TrGF. For such transgressive, "chthonic paeans" in tragedy, see (e.g.) Aesch. Cho. 149-151; Soph. Trach. 205-224; Eur. Hel. 174-178, IA 1475-1531, with discussion by Rutherford 1994-1995 and Weiss 2014.

63 Cannatà Fera 1990: 139-144; for this characteristic pivot in Pindaric (and Bacchylidean) priamels, see also Carson 1984: 116-119.

64 Cannatà Fera 1990: 143-144; as Cannatà Fera notes, unlike the other three, Orpheus' name does not correspond to the name of a particular song-type. Ford 2002: 16 in a somewhat different way from Cannatà Fera recognizes the mention of Orpheus as a moment of thematic shift or mediation: on Ford's reading, Orpheus, in his attempt to rescue Eurydice 
Cannatà Fera's intuition gains support from the imagery and epithets of these opening lines. Leto, mother of Apollo and Artemis, is "gold-spindled" in line 1; as often in Pindar, the divine is associated with the incorruptible glitter of gold. ${ }^{65}$ At the same time, songs in honor of the gods are aligned with seasonal renewal and repetition: paean songs are $̈$ pı $\alpha$ ( "in due season," line 2), while the dithyramb of Dionysus is associated with the flourishing vegetation of his crown(s) (line 3). ${ }^{66}$ In contrast, with the three dead sons of Calliope, the epithets and imagery focus on their mortal bodies and progressively emphasize

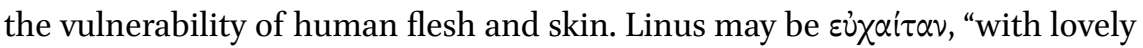
hair" (line 6), underscoring his youthful beauty, ${ }^{67}$ while Hymenaeus dies or dis-

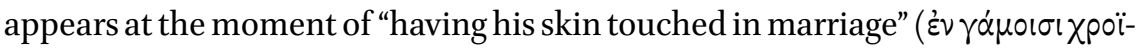

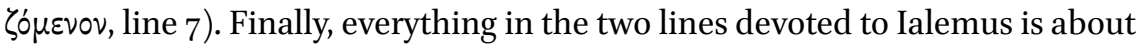
the vulnerability of mortal body and mortal flesh — he is "shackled in strength" ( $\pi \varepsilon \delta \alpha \theta \dot{\varepsilon} v \tau \alpha \sigma \theta \varepsilon^{\prime} \nu \circ \varsigma$, line 10) by a disease that "strikes raw flesh" ( $\left.\omega \mu \circ \beta \dot{\lambda} \lambda \omega\right)$, or per-

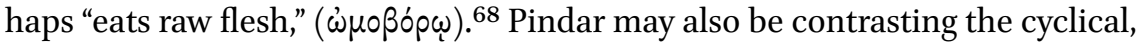

from the underworld, crosses the mortal-immortal divide constructed by the earlier terms of the priamel.

65 For the classic study of gold in Pindar, see Duchemin 1970. Leto is likewise "gold-spindled" at Nem. 6.36; for other goddesses to whom the same epithet is applied, see $\mathrm{Ol} .6 .104$ (Amphitrite); Nem. 5.36 (Nereids); fr. 29.1 SM (Melia).

66 Indeed, we even find a contrast within the different types of divine songs, since paeans are seasonal, sung in the spring ( $\omega_{p}(\alpha)$ ), while the "flourishing ivy" of Dionysus' crowns is evergreen.

67 We say "may" because there are three different plausible readings here: (1) We follow

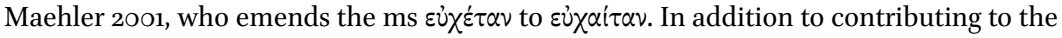

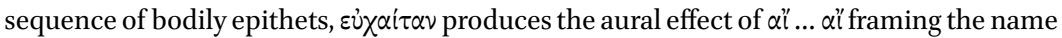
of Linus in the line, thus miming the mourning exclamation over the dead son. (2) Cannatà Fera (1987: 19-20, 1990: 150-152) defends the ms reading عن̉ ₹́์ $\tau \alpha v$. Although this adjective is otherwise attested only in late Greek, Cannatà Fera contends that it is characteristically

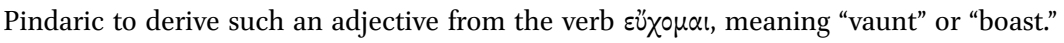
Thus, she argues, the derived adjective means "vaunting" or "boastful," and she connects it with the tradition that Linus was killed by Apollo for "likening himself to him in song" (Paus. 9.29.6; cf. Carm. Pop. fr. 88o PMG and the report of Philochorus preserved in the scholia to Iliad 18.570). With this epithet, as Cannatà Fera 1987: 20 points out, the poet alludes to the cause of Linus' death, just as he does more explicitly with Hymenaeus and

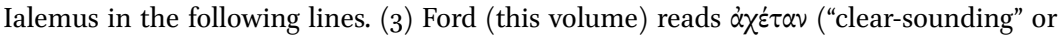
"resounding"), which had been taken to be the ms reading before Cannatà Fera's careful reinspection of the text, and notes that "the epithet underscores [the] sonic power" of Linus' name as a refrain. As Donald Mastronarde points out to us, the ms reading عù $\chi^{\varepsilon-}$ $\tau \alpha \nu$ would represent a very easy corruption phonetically and paleographically from either

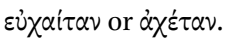

68 These are both emendations for the text's nonce-word $\delta \mu \circ \beta \dot{0} \lambda \omega ; \omega \mu \circ \beta \dot{\omega} \lambda \omega$ is Hermann's

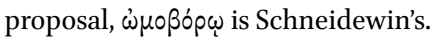


seasonal temporality of songs to the gods with brief, circumscribed mortal time and its sudden foreclosure. Reading voxтi at the beginning of line 8, Hymenaeus disappears suddenly "one night"; Pindar may emphasize the abruptness of his disappearance by the juxtaposition of "first" and "last" in the same line. ${ }^{69}$

But with Orpheus, everything changes. We seem to shift again from mortal, vulnerable bodies to immortal, golden attributes. Orpheus is $\chi p \cup \sigma \alpha \dot{\alpha} 0 p \alpha$, which in this context presumably means "with golden lyre."70 The "gold" sends us back to Leto's epithet in the opening line, while the possession of a golden lyre strongly identifies Orpheus with Apollo himself.71 It seems likely that the mention of Orpheus (the third term of the priamel) leads into or introduces Pindar's own song. The play of epithets suggests that Orpheus stands here for the transcendence of mortality through the immortal power of song, in what would simultaneously be the conjuncture or synthesis of the two different generic types in a new form of lyric.

Thus Plato's Laws represents pure ideology, lamenting a lost Golden Age of pristine, unmixed genre, while Pindar's fragment boldly enacts a dazzling genre mixture to transubstantiate a dead body into immortal song. Within the complex literary and cultural space of genre, ancient theory and ancient practice go their separate ways and pursue their different ends.

Several of the papers in the volume offer readings of such generic selfconsciousness and dynamic generification or genre hybridity in archaic and classical Greek poetry. In addition to Ford's analysis of Homer as playful ethnographer of the Linus song, Timothy Power argues for a complex dialectic of the broad categories of choral and monodic song within the poems of Sappho, while Mario Telò tracks the intermittent engagement of rough, abrasive iambic with the soft, luxurious phonics, thematics, and affect of Sapphic monody in his contribution. Naomi Weiss, as already mentioned, explores tragedy

69 Donald Mastronarde, based on his own inspection of the ms under UV light, confirms the reading vuxti for the beginning of the line. The rest of line 8 is problematic (there is no subject to govern $\lambda \dot{\alpha} \beta \varepsilon v)$, so it is difficult to tell what "first" and "last" refer to here.

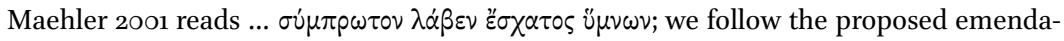
tions of Henry 1999: 14 ("whom his last sleep took together with his first night").

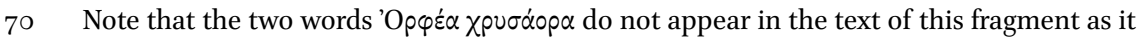
is transcribed by the scholiast to Euripides' Rhesus; the phrase is preserved by a scholion to Iliad 15.256 (4.67.16 Erbse), and was added to the text of fr. 128c SM by Bergk, who is followed in this by all subsequent editors. Snell then suggested on the basis of the meter and the exact responsion of $\chi p v \sigma-$, that these words may form the beginning of the antistrophe.

The other traditional meaning of the epithet $\chi p v \sigma \alpha \dot{\alpha} \rho \alpha \alpha$, "with golden sword," may

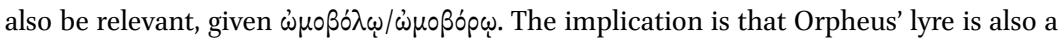
weapon or defense against the ravages of mortality. 
as a "super-genre," while Margaret Foster offers a detailed reading of a particular instance where different genres seem to cohabit within a single composition of Bacchylides without losing a sense of their own generic autonomy. Finally, Deborah Steiner describes what she calls the "genre contamination" of early hexameter and choral song through choruses as catalogues and catalogues as dancing choreuts.

\section{The Ritual and the Fictional}

Our second point is very closely connected with our first. If the texts we have are always already literary and instantiations of secondary genres not entirely subsumable to a single original performance occasion, we need to allow more scope in our interpretations for elements of the fictive or fictional as a complement to ritual elements within archaic and classical Greek poetry. Here scholars in different areas and periods of literary studies provide potentially powerful models to think with. Thus, for example, Roland Greene proposes that "lyric discourse is defined by the dialectical play of ritual and fictional phenomena, or correlative modes of apprehension that are nearly always available in every lyric, though particular specimens, collections, and schools may try to protect one at the expense of the other."72 $\mathrm{He}$ acknowledges that his is a phenomenological approach, concerned with the "modes of apprehension" of lyric by its audience(s). By "ritual element," Greene means "the poem's office as directions for a performance" —all those qualities of sound, prosody, rhetoric, semantics, and symbolism that enable it to take over any speaker, making it compulsory, communal, and eminently repeatable. ${ }^{73}$ In contrast, Greene defines lyric's fictional mode or capacity as:

the poem's other identity for apprehension, not as potentially immediate but as represented speech. ... A lyric's fictional capacities are enlisted in various ways: where the reader is able to construe the poem as a 'speaking, addressing, expressing, [or] alluding' within a hypothetical context that articulates and holds the boundaries between self and things, subject and object, and so on; where the history evoked by the work is not merely

\footnotetext{
$72 \quad$ Greene 1991: 5 .

73 Greene 1991: 5-10; quotation from p. 5. Note that for Greene, "ritual" is actually a metaphorical category, whereas for us dealing with archaic and classical Greek poetry, it is literal. Culler 2015 depends heavily on Greene's "ritual element" for his model of lyric while disavowing Greene's "fictional mode" as its complement.
} 
coextensive with its performance; where the poem's voice is posited not as the reader-auditor but as a character; where temporality has been addressed through some formal strategy equivalent to a plot; and where the fortunes of tone, rhetoric, and meter are susceptible to analysis within that plot. ${ }^{74}$

Greene formulates his model of lyric discourse as an interaction or dialectic of ritual and fictional modes in the context of reading lyric sequences, starting with Petrarch's Canzoniere and tracing out what he defines as a long tradition of "Post-Petrarchism." Because he is reading lyric sequences, Greene is particularly interested in counterposing the fictional, narrative capacity of lyric to its ritual dimension, but nonetheless, he insists that both modes of apprehension are available in the reading of individual lyrics as well. ${ }^{75}$ As we shall see, the concept of lyric sequence may in fact be relevant for iambic and for lyric monody, but even on the level of the individual poem, Greene's notion of ritual and fictional elements "interrogating" each other, or helping to establish each other's primacy, promises to be useful in the reading of archaic Greek poetry.

Another way of getting at certain kinds of complexity that the oralist/performance/occasion paradigm has perhaps discouraged us from exploring (and one entirely consonant with Greene's model) is Eve Sedgwick's concept of the "periperformative." Writing mainly about the nineteenth-/twentieth-century novel, Sedgwick is interested in narrative moments that seem to pullulate around actual performative utterances, where the latter are defined as the public, official, efficacious speech constituted by the first-person singular, present indicative active verb. ${ }^{76}$ Sedgwick's prime example of the performative is the matrimonial, "I now pronounce you man and wife," or "I do," but her model applies to other performatives embedded in poetry and narrative as well. ${ }^{77} \mathrm{In}$ relation to these, she is fascinated by the unofficial, private statements referring to performatives that seem to spring up in spatial proximity to them. These periperformatives are unauthorized, often negated and katachrestic; they can be expressions of affect and subjectivity in relation to the performative. They also borrow from or mobilize many different speech genres simultaneously,

\footnotetext{
74 Greene 1991: 10; the quotation within his quotation is from Smith 1978: 28.

75 Greene 1991 passim; see esp. 11-17.

76 Sedgwick 2003, following and elaborating the definition of the "performative utterance" by the philosopher Austin (1975). For further discussion of periperformatives applied to the poetry of Cavafy, see Sedgwick 2011: 53-67.

77 Matrimonial performatives are more relevant for the nineteenth-century novel, whereas for Cavafy's lyric, Sedgwick is much more attuned to the ritual performative of prayer and its periperformative deformations.
} 
whereas (as she notes) the performative utterance derives its efficacy from being just one thing (a valid marriage ceremony cannot also be an oath-taking or a christening). ${ }^{78}$ And as the performative clearly aligns with ritual, so Sedgwick's periperformative roughly overlaps with Greene's "fictional mode."

In fact, something like Greene's axis or model has already emerged within the field of archaic Greek poetry from the current intense interest in reperformance. Already in his 1994-1995 article "Genre and Occasion," Gregory Nagy had proposed that individual Pindaric epinicia were characterized by an overloading of cues for different occasions and performance contexts, such that each epinician incorporated its own past performance history and anticipated its posterity in reperformance via deictics and other signals. Subsequent scholarly focus on deictics and reperformance in Greek poetry has fully borne out Nagy's contention, leading to a recognition that some of the deictics and performance cues within any particular setting have to be fictive. ${ }^{79}$ This has led in turn to an acknowledgment among Pindarists that within any given poem, Deixis ad oculos and Deixis am Phantasma are formally indistinguishable, and are meant to be, in order to facilitate multiple performances in multiple venues. ${ }^{80}$ In addition, other studies have recognized that it is not just place or occasion that can shimmer in and out of fictionality within the Pindaric ode, but also its temporality, shifting between the moment of composition and that of performance, and the speaking ego, which can oscillate between a member of the communal komos and the professional poet who stands apart from it. ${ }^{81}$

Nagy's own approach to such overloading or oscillation has been to subsume the fictional within the ritual, insisting that all such shifting references are to different ritual occasions, so that the poem itself "absolutize(s) occasion." 82 Thus for Nagy (as for Calame), it is ritual all the way down. ${ }^{83}$ Such an

78 Sedgwick 2003: 67-80.

79 On deixis, see especially Felson 1999; essays collected in Felson, ed. 2004; Edmunds 2008; Athanassaki 2011.

80 See esp. Bonifazi 2004, Ferrari 2012; cf. Morrison 2007, 2012 on reperformance. For a different articulation of the complex fictive settings of Pindaric epinicia, see Agócs 2012, and for a different approach to reperformance, see the essays of Hunter and Uhlig 2017, which develop theories from modern performance studies to emphasize that there is always a gap or mediation in "performance"; that all performance is reperformance.

81 For temporality, see especially D'Alessio 2004, followed by Morrison 2007. For somewhat different approaches to epinician temporality, cf. Budelmann 2017, Spelman 2018. For the shifting positionality of the Pindaric ego, see Morgan 1993; Kurke 2005; Currie 2013; Maslov 2015: 97-116.

82 Nagy 1994-1995: 19; see also his Keynote in this volume.

83 This is also perhaps the motivation behind the insistence of scholars of the anthropologi$\mathrm{cal} /$ oral/ritual school that Sappho too must be choral: thus Calame 1977, 2009c; Lardinois 
approach tends to gloss over complexities we might better grasp with something like Greene's model: "even to privilege one [ritual or fictional element] is usually a matter not of ignoring the other, but of subsuming it so that it helps rather than hinders the establishment of the other's primacy." ${ }^{84}$ Thus we might rather say that Pindaric poetics mobilizes the fictional to buttress and assert the ritual authority of epinician as a latecomer genre of choral poetry.

Following Greene's model of lyric discourse as a dialectic of ritual and fictional elements would also allow us to keep both meanings of mimesis in play for archaic Greek poetry-that is, both the ritual meaning ("reenactment") and its sense as fictional "imitation," which for Nagy represents an abrupt diachronic shift. Following Greene's model, we might say that it is precisely the shimmering oscillation of ritual "reenactment" and fictional "imitation" that characterizes this poetry and leads inevitably to full-scale drama that is also still ritual. ${ }^{85}$ Alternatively, in Sedgwick's terms, we might think about choral lyric as the domain of the performative par excellence-as scripts for ritual or for ritualization. ${ }^{86}$ In these terms, we might see Pindar's generically overstuffed epinicia as urgently soliciting the special authority of choral poetry by posing as multiple performatives simultaneously.

In contrast to choral lyric, Greek monodic or sympotic forms seem to have encouraged or accommodated more extreme forms of fictionalization, and this may have much to do with the temporary license and ludic space provided by the ancient symposium as a context secluded from the public sphere. ${ }^{87}$ Within iambic, such fictionalization has often been recognized, though usually under

1996; Nagy 2007, 2016, etc. For critiques of ritualist/choralist readings of Sappho, see Yatromanolakis 2004, D'Alessio 2018, and the essay by Power in this volume.

84 Greene 1991: 12. Note that Greene is talking here about the practices and priorities of both poets and critics. So we might say that this style of deploying the fictional to help promote the primacy of the ritual mode characterizes both Greek choral poetry and the Nagy/Calame reading thereof.

85 This is also perhaps a useful conceptual framework to apply to Henrichs' concept of "choral projection," which strikingly occurs in both non-dramatic and dramatic choral poetry (Henrichs 1994-1995, 1996a, 1996b). On the continuity of this phenomenon between archaic lyric and classical drama see Power 2000; Weiss 2018; also Kowalzig 2007b: 13-55 on the fusion of past and present, myth and ritual, through the "hinge" of choral performance.

86 For "ritualization," see Bell 1992; for application of the concept to Greek choral poetry, see Kurke 2005, 2007; Kowalzig 2007b: 40-43. This is perhaps what ultimately motivates Nagy's identification of performance and the Austinian performative (as noted above, p. 5) - and why his model in fact works best for choral poetry.

87 For this, see esp. the essays collected in Murray, ed. 199o; Kurke 1996; Morris 1996, 200o: 178-184; Neer 2002: 9-26; Collins 2004. 
the rubric of poetic "persona." 88 Thus one compelling reading of the fragments of Archilochus and Hipponax sees the iambist as a generically low figure, a scapegoat with the power to scapegoat others, often cast in the role of a burlesque or picaresque Odysseus traversing a nightmare world of filth, violence, and sex. ${ }^{89}$ And here, the concept of lyric sequence may be important, as scholars have noted implied narratives that arc across many individual fragments. ${ }^{90}$

In a very different register, monodic lyric too seems to open up a space for fiction or fictionalization. For this, we need look no further than Sappho fr. $1 \mathrm{~V}$. We are accustomed to refer to this poem as the "Hymn to Aphrodite," but in fact, the quicksilver movement of this song effortlessly eludes any straightforward ritual reading. Although it begins as a word-perfect cletic hymn, it rapidly morphs into narrative of a past epiphany of Aphrodite (which cannot be assumed to be a normal part of a real ritual hymn). ${ }^{91}$ As scholars have long recognized, the speaker "Sappho" here thus assumes the role of an epic hero-an amatory Diomedes or Odysseus, enjoying a close, intimate relation to a patron goddess. ${ }^{92}$ And, as in the case of iambic, it is suggestive that Sapphic monody seems interested in exploring the fictive and narrative capacities of the lyric sequence - whether this be through multiple poems of love and separation, or (as the newest papyrus finds make abundantly clear) through multiple snapshots of an ongoing family drama. ${ }^{93}$ Nor is this kind of fictionalized lyric sequence restricted to Sapphic monody. Such a model would well accommodate the narrative thrust of Alcaeus' $\sigma \tau \alpha \sigma i \omega \tau i x \dot{\alpha}$, which, as far as we can tell, were organized already in the Hellenistic edition in a chronological and thematic sequence (first exile; betrayal of Pittacus; second exile, etc.). ${ }^{94}$

Sedgwick's periperformative provides a complementary way of thinking about iambic and monody in relation to public ritual performative utterances (including choral lyric). Thus we might take iambic $\beta \omega \mu$ $\omega \lambda$ oxi $\alpha$ (literally, "skulking around the altar") as emblematic of this-on the disreputable fringes of

88 See already Dover 1964; West 1974: 26-33; Nagy 1976, 1979: 243-252.

89 Miralles and Portulas 1983, 1988. See also Seidenstücker 1978; Rosen 1988; Miller 1994: 9-36.

$90 \quad$ Miralles and Portulas 1983, 1988.

91 On lyric, narrative, and anti-narrative in this poem, see Purves 2014.

92 This fictive or narrative element is implicit in the readings of Rissman 1983; Winkler 199o; Hutchinson 2001: 149-160.

93 On Sappho's Brothers Song as part of an extended song cycle on (fictional) brothers and family relations, see Lardinois 2016; Peponi 2016.

94 On the organizational principles of the Hellenistic edition of Alcaeus, see Acosta-Hughes 2010: 134-140; cf. Hutchinson 2001: 192-194, discussing a particular sequence of "exile poems" in a sanctuary. 
ritual, but not the ritual itself.95 Likewise for Sappho and Alcaeus: Timothy Power, in his essay in the volume, argues forcefully for what he calls Sappho's "parachorality"-her frequent conjuring within monodic song of choral forms and choral value. This, as he notes, seems to be a particular feature of Sapphic song, which frequently mentions choruses and choral song, although it is never clear that the chorus mentioned is actually performing the composition. In addition to offering a clear instance of the fictional element in Sappho, Power's concept of parachorality neatly aligns with Sedgwick's periperformative. ${ }^{96}$

Given this alignment and Power's reading of Sappho fr. $17 \mathrm{~V}$ as extended parachorality unmarked by any frame, we are tempted to suggest that $\pi \lambda \dot{\alpha} \sigma 10 \mathrm{~V}$, the mysterious first word of this poem, is the "nearby" of the periperformative. That is, not in the temenos of Hera, where choruses sing, but nearby. ${ }^{97}$ At the same time, Sedgwick's subtle analysis gives us a different vocabulary to characterize those non-speech acts that crowd around the performative and refer to it. For Sedgwick, these moments are often peculiarly imbued with affect, and they may ironize or negate the pure force of the performative, as much as simply invoke its power. Such a model might usefully be applied to a reading of Alcaeus fr. $130 \mathrm{~B}$ V, with which Power ends his discussion (as a striking instance of Alcaean parachorality). Here the speaking ego portrays himself as a miserable exile out in the wilds, longing to hear one performative utterance that is distinctly male and civic (the summoning of the assembly and the boule) while almost inadvertently stumbling into a very different performative, the ritual "uncanny echo of the sacred, yearly ululation of the women" (fr. 13oB, lines 1920). It is difficult to gauge the tone and mood of our speaker, fictively isolated and suspended in a no-man's land between two gendered ritual cries. Power opts for a more optimistic community-building reading of Alcaeus's closural parachoral gesture, but we might follow the interpretations of Anne Pippin Burnett and Anne Carson, to parse the ego's alienated periperformative in the middle of the song as more self-ironizing and bitterly negative. ${ }^{98}$

95 Note Hipponax's periperformative play with prayers in frr. $34,35,36$, and $38 \mathrm{~W}$.

96 Cf. Yatromanolakis 2004 for analogous arguments about Sappho's poetry framed in terms of a distinction between performative and descriptive contexts. See also the important discussion of D'Alessio 2018; D'Alessio notes that Sapphic lyric seems to favor a position of "marginality" in relation to communal, ritual performances (discussing esp. Sappho frr. 17, 22, 27, and the Brothers Song).

97 Cf. D'Alessio 2018: 45 for a similar reading of the mysterious opening word of Sappho fr. 17 .

98 Thus Burnett 1983: 176-181; Carson 1995: 119-126; such a reading of Alcaeus might productively engage with Sedgwick's (2011) reading of periperformatives in Cavafy. 
In addition to Power's essay, several other contributions to the volume also engage the issue of the interplay of ritual and fictive elements within archaic and classical Greek poetry. Olsen approaches this issue through the performance and reperformance of Pindaric paean, while Weiss considers how enactments and evocations of different ritual performances track and drive the dramatic narrative of a tragedy.

\section{Materiality, Affect, and the Body}

Finally, several of our contributors bring to bear on the issue of genre in archaic and classical Greek poetry new theoretical approaches concerned with materiality, affect, and the body and bodiliness. All these critical movements (closely connected with each other) comprise the "material turn," itself a reaction to the abstraction and logocentrism of the "linguistic turn" represented by structuralism, semiotics, deconstruction and other versions of poststructuralism. At the same time, these versions of the material turn aim to further poststructuralism's critique and decentering of the unquestioned hegemony of the individual autonomous subject. Thus the "New Materialisms" reject the hierarchy of subject and object, positing a more equal, horizontal relation between them; the agency of objects; and even the objecthood of human bodies as "walking minerals." ${ }^{99}$ In like manner, affect theory aims both to materialize and to depersonalize "emotion," substituting for the model of internal, private feelings "affects" that circulate freely and contagiously among bodies, and between subjects and objects. ${ }^{100}$ While materiality, affect, and bodies are all hot topics throughout the humanities at large, attention to them also represents an organic and logical development of the oralist/ performance/ occasion paradigm. So, for example, Claude Calame's emphasis throughout his work on the initiatory function of ritual song and dance already points us to the importance of the body, embodied practices, and embodied knowledge. In a sense, his model of the functioning of "choruses of young women" is analogous to Bourdieu's habitus, the slow, sedimented bodily inculcation of all that "goes without saying because it comes without saying," or to Catherine Bell's notion that the goal of repeated ritual acts is the formation of "ritualized bodies." 101

99 See (e.g.) Gell 1998; Latour 2005; Bennett 2010.

100 See (e.g.) Deleuze and Guattari 1987; Sedgwick 2003; Ahmed 2004; Altieri 2007; Seigworth and Gregg 2010.

101 For the connections among habitus, bodily practices, and the experience of doxa, see 
In these terms, the focus on materiality, affect, and the bodily gives us new ways of grounding and specifying what exactly performance does and how it does it. To consider affect first: Mario Telò provides this concise definition in his essay in the volume:

Affect theory views emotion as a boundless exchange of feeling, circulating beyond bodily boundaries, blurring the distinction between subject and object, the source or producer and the target or receiver. Feeling, in this perspective, becomes a dispossessed, impersonal, contagious force.

This model of affect helps us think in new ways about the sensory crossover or intimate bodily identification of performers and audiences that several scholars have argued for as a distinctive feature of Greek poetry in performance. ${ }^{102}$ At the same time, because theorists of affect are interested in tracking at the micro-level the psychic and bodily effects of form, they offer us finer instruments to analyze the interaction of elements of performance and literary/formal features within Greek poetry. ${ }^{103}$ Telò puts all these aspects of affect theory to work in his contribution to the volume, capturing a distinctive iambic affect of horror - the rough, sado-masochistic thrills of pleasurable pain generated in performer and audience alike by the materiality of iambic language (specifically, the rough rho and broken rhythms of Archilochus, Hipponax, and their later imitators).

Similarly, Seth Estrin in his essay in the volume focuses on the materiality and bodily effects produced by the distinctive structure of funerary elegy, read in intimate connection with its material support in the context of a particular monument (the Ambracian polyandrion). For Estrin, both the formal structure of the elegiac couplet and the materiality of the stone cenotaph enact a disjunctive logic of presence and absence that elicits in the reader/viewer of the inscribed monument the same experience of loss and mourning felt by the philoi and fellow citizens of the dead. The speaking, mourning monument thus takes over its reader, controlling his movements, and thereby interpellates him as mourner and citizen. Olsen's paper also focuses on embodied practices and embodied experience, to reconstruct how the specifics of "embodied cultural knowledge" contribute to the distinctive "feel" of paean even in individual, sympotic reperformance. Her paper also moves beyond something like Bourdieu's

Bourdieu 1977: 78-95, 164-171, 1990: 52-79 (quotation taken from Bourdieu 1977: 167). For the formation of "ritualized bodies" as the goal of ritualization, see Bell 1992: 94-117.

102 See Peponi 2009, 2012; Kurke 2012, 2013a; Olsen 2017.

103 See (e.g.) Ablow, ed. 2010; Brinkema 2014. 
model of habitus or Bell's of the formation of ritualized bodies, since Olsen borrows from dance theory the theoretical tools to track not just the proper social formation of bodies but also their potential resistance.

All three essays offer us new definitions of genre attentive to bodies and affect - what we might call the somatics and atmospherics of genre. Thus Telò boldly proposes that we think of genre as "the material environment created by the unlimited circulation of lyric affect, inside and outside the poetic frame." For Estrin, the funerary elegy and the mourning monument configure a particular "structure of feeling," a generic form that also structures the viewer's experience. And Olsen adapts the concept of "embodied cultural knowledge" from dance theory to propose that we think of a genre like paean as a distinctive structure of somatic memory.

In light of the theoretical work done by these papers, we can see the importance of the themes of materiality, affect, and the bodily also in other contributions to the volume. Sarah Olsen's notion of genre as an archive or repertory of "embodied cultural knowledge" that conjures up particular memories and affects in (re)performance is suggestive for Deborah Steiner's essay. For the latter, too, is very much about the bodiliness - the somatics - of catalogues, which may perhaps have evoked strong associations of choral performance in their ancient audiences. Likewise, Olsen's model of genre is very relevant for Mark Griffith's contribution on Korybantic (and other ecstatic) performances as a lyric genre. For, as Griffith compellingly demonstrates, these ubiquitous "subliterary" performances do indeed constitute a genre-a genre most of all defined by a particular configuration of the bodily and affective states they elicit in their participants. In addition, Griffith's close reading of Aristotle's Politics Book 8 reinforces an important point made by Schironi's paper: modern scholars tend to think that ancient theorists of literature almost entirely ignore the domain of performance, so that their essentializing, moralizing taxonomies of genre have little to contribute to modern analysis, but we have perhaps been looking in the wrong places. Just as Schironi briefly considers ancient treatises on dance that are much more engaged with the performative and bodily aspects of Greek song than, for example, the scholia to Pindar, Griffith showcases Aristotle as an astute theorist of the bodily and affective powers of music in performance. That is to say, if we look beyond the Poetics, Aristotle seems to anticipate in striking ways many of our current critical and theoretical concerns. Finally, that the bodily and affective may also, to some extent, lurk behind the familiar categories of the Poetics is suggested in turn by Naomi Weiss' essay in the volume. For, as she notes, the play within tragedy of different embedded lyric genres that anticipate or stage the turns of the plot were likely to have cued the embodied memory of many audience members, thus 
grounding (for example) Aristotle's characteristic tragic emotions of pity and fear in the audience's kinesthetic bodily reactions.

The multiple points of intersection among these different approaches demonstrate the breadth and inclusivity of the volume as a whole, which aims neither to promote nor foreclose any one definition of genre. We hope that the papers here, read individually and especially together, will open up new ways of thinking about genre in archaic and classical Greek poetry. 